\title{
RLIP76 GENE VARIANTS ARE NOT ASSOCIATED WITH DRUG RESPONSE IN TURKISH EPILEPSY PATIENTS
}

\author{
Manguoğlu E ${ }^{1, *}$, Akdeniz $\mathrm{S}^{1}$, Dündar $\mathrm{NO}^{2}$, Duman ${ }^{2}$,
} Aktekin $\mathrm{B}^{3}$, Haspolat Ş$^{2}$, Bilge $\mathrm{U}^{4}$, Özel D ${ }^{4}$, Lüleci $\mathrm{G}^{1}$

\begin{abstract}
*Corresponding Author: Esra Manguoğlu, Department of Medical Biology and Genetics, Faculty of Medicine, Akdeniz University, Antalya, Turkey;

Tel.: +90-242-249-6977; Fax: +90-242-249-6906; E-mail: emanguoglu@akdeniz.edu.tr
\end{abstract}

\begin{abstract}
Approximately $30 \%$ of epileptic patients remain untreated, in spite of trials with maximum tolerable doses of more than one drug. The RalA binding protein 1 (RALBP1/RLIP76), a multifunctional, anti-apoptotic, multidrug transporter protein, has been proposed as being responsible for the drug resistance mechanism in epilepsy. We have investigated polymorphic differences in the coding regions and exon-intron boundaries of the RLIP76 gene, between 146 refractory and 155 non refractory epileptic patients in Turkey, using denaturing high performance liquid chromatography (HPLC) and sequencing analysis techniques. We have detected the following sequence variants: c. $160-4 \mathrm{G}>\mathrm{A}, \mathrm{c} .187 \mathrm{C}>\mathrm{G}$, c. $1562-38 \mathrm{G}>\mathrm{A}, \quad$ c. $1670+107 \mathrm{G}>\mathrm{A}, \quad$ c. $1670+93 \mathrm{G}>\mathrm{A}$, c. $1670+96 \mathrm{G}>\mathrm{A}, \quad$ c. $1670+100 \mathrm{C}>\mathrm{T}, \quad$ c. $1670+130 \mathrm{C}>\mathrm{T}$, c. $1670+131 \mathrm{G}>\mathrm{C}$, c. $1670+140 \mathrm{G}>\mathrm{C}$, and found no statistically significant correlation between allele frequencies and drug response status. We conclude that
\end{abstract}

Department of Medical Biology, Faculty of Medicine, Akdeniz University, Antalya, Turkey

2 Department of Pediatric Nuerology, Faculty of Medicine, Akdeniz University, Antalya, Turkey

3 Department of Neurology, Yeditepe University Hospital, Istanbul, Turkey

4 Department of Biostatistics and Medical Informatics, Faculty of Medicine, Akdeniz University, Antalya, Turkey sequence variants of this gene are not involved in drug resistance in epilepsy.

Keywords: Epilepsy; Neuropharmacology; Pharmacogenetics; Polymorphism; RLIP76 gene

\section{INTRODUCTION}

Drug resistance in epilepsy is one of major obstacles in clinical medicine. In a 37-year follow-up study, $67 \%$ of 144 patients were reported to be in remission at the end of follow-up, while $14 \%$ of the patients relapsed after a period of remission and did not re-enter remission, and remaining $19 \%$ of the patients never entered remission during the whole period of follow-up [1]. Optimum doses of anti-epileptic drugs (AEDs), prognosis and treatment outcomes showed considerable variation in the patients and could mostly be attributed to genetic variation between individuals [2]. Genetic variants of some proteins that are responsible for drug absorption, distribution, metabolism and elimination, have been extensively studied [3].

The RalA binding protein 1 (RLIP76 or RALBP1) is a protein that has been proposed to be associated with drug resistance in epilepsy [4]. It binds ras-related v-ral simian leukemia viral oncogene homolog A (RalA) and modulates the Rho pathway through the Ras pathway [5]. It is also involved in the transport of glutathione (GSH) conjugates and xenobiotics and in modulating drug sensitivity in cancer cells [6]. It 
was shown that RLIP76 is the major ATP-dependent transporter of GSH conjugates as well as doxorubicin in human erythrocytes [7]. More recently, Rossé et al. [8], proposed that RLIP76 is required for Epsin phosphorylation to switch endoyctosis off. RLIP76 was shown to be required as an effector for PKC $\alpha$ that is protein kinase transmitting downstream signals in response to stressors such as chemotherapeutic agents [9]. Moreover, RLIP76 is induced by oxidative stress and has been suggested to play a role in insulin resistance under increased oxidative stress [10].

RLIP76 is expressed in normal human breast, heart, liver, erythrocytes, and, to a lesser extent in colon and brain parenchymal tissues [4]. Blood vessels from refractory and non refractory epileptic brain tissues showed higher levels of expression, predominantly in the endothelium. It was also demonstrated that RLIP76 is an important carbamazepine and phenytoin transporter in human epileptic brain tissue. As a result, investigators proposed that RLIP76 might be involved in a drug-resistant epilepsy mechanism [4]. On the contrary, immunohistochemical analysis revealed that RLIP76 was co-localized with a neuronal, but not epithelial marker, in normal and epileptic brain tissues. In addition, no association was found between six common single nucleotide polymorphisms (SNPs) of the RLIP76 gene and 262 drug-responsive and 107 drug-resistant patients. Also, no correlation was found for susceptibility for epilepsy in 783 epilepsy patient and 359 healthy controls [11]. Moreover, a separate study failed to show any association between 13 common RLIP76 polymorphisms and drug-response in epilepsy in a prospective cohort of 503 epilepsy patients [12]. In this study, to further investigate the association between RLIP76 and drug response in epilepsy, we performed genotype analysis for the RLIP76 gene and statistical analyses for any association in refractory and drug-responsive groups.

\section{MATERIALS AND METHOD}

Patients. A total of 146 (81 male and 65 female) refractory and 155 (79 male and 76 female) non refractory patients were recruited for the study. The mean age for refractory and non refractory groups were 34.4 \pm 17.8 (ranging from 3 to 83 years) and $25.4 \pm 17.5$ (ranging from 2 to 78 years), respectively. One-hundred and forty-three the patients were above the age of 18 , while 158 patients were below the age of 18 .
Patients who were seizure free for at least 1 year were regarded as non refractory epilepsy patients. Patients, who had seizures, in spite of taking at least three different AEDs with maximum tolerable doses, were considered to be refractory epilepsy patients.

This study was approved by the Akdeniz University Ethics Committee (Antalya, Turkey). Information about the study was given to all patients. A signed, informed consent was obtained from all patients or from adults responsible for them. Patients were recruited from Akdeniz University Hospital, Departments of Pediatrics and Neurology (Antalya, Turkey). All patients were Turkish.

Genotyping. DNA isolation from peripheral leukocytes was performed by a standard salting-out method [13]. All coding exons (exons 2-10) and exon-intron boundaries of the RLIP76 (RALBP1, NM_006788.3) gene were screened for sequence changes by denaturing high performance liquid chromatography (HPLC). The polymerase chain reaction (PCR) primer sequences are given in Table 1. The PCR reactions were set up in $20 \mathrm{ML}$ volume with 10-20 ng DNA, 0.5 U Optimase Taq DNA polymerase, using a PE9700 thermal cycler [Applied Biosystems Inc. (ABI), Foster City, CA, USA]. Amplifications were done by touch-down PCR with annealing temperature with decreasing increments of $0.5^{\circ} \mathrm{C}$ in each cycle starting from $61^{\circ} \mathrm{C}$ to $54^{\circ} \mathrm{C}$. Denaturing HPLC analyses were performed on a Transgenomic (Omaha, NE, USA) Wave HS nucleic acid fragment analysis system with DNASep cartridges, WAVE Optimized buffers and standards. To increase the sensitivity of these analyses, they were performed on at least two different oven temperatures for each PCR fragment. All regions that have denaturing HPLC patterns suggesting a sequence change were sequenced successfully to define the sequence change. The PCR products were purified using a Roche High Pure PCR product purification kit (catalog no. 11732676 001; Roche Applied Science, Indianapolis, IN, USA). A direct sequencing protocol was applied and BigDye Terminator v.1.1 cycle sequencing system was used (Applied Biosystems). Sequencing samples were separated using an ABI $3130^{\mathrm{TM}}$ system (Applied Biosystems).

Statistical Analysis. When minimum expected values were less than 5, the Fisher's Exact test was used. When the minimum expected value was between 5 and 25, the Yate's Continuity Correction test was used. In all other circumstances, the Pearson $\chi^{2}$ (Chi-square) test was used. Statistical analysis was performed with SPSS version 15 (SPSS Inc., Chicago, 
IL, USA); $p<0.05$ was considered to be statistically significant.

\section{RESULTS}

We have not detected any sequence change in the coding regions of the gene. However, two substitutions within the 5'UTR (5' untranslated region) (c.160-4G $>$ A, c. $187 \mathrm{C}>\mathrm{G}$ ); eight substitutions within the intronic regions (c.1562-38G $>$ A, c. $1670+107 \mathrm{G}>\mathrm{A}$, c. $1670+93 \mathrm{G}>\mathrm{A}, \quad$ c. $1670+96 \mathrm{G}>\mathrm{A}, \quad$ c. $1670+100 \mathrm{C}>\mathrm{T}$, c. $1670+130 \mathrm{C}>\mathrm{T}$, c. $1670+131 \mathrm{G}>\mathrm{C}$, c. $1670+140 \mathrm{G}>\mathrm{C}$ ) were detected. The c.187G $>\mathrm{C}$ change was detected in two refractory and one non refractory patients, the c. $1670+93 \mathrm{G}>$ A change was detected in four refractory and six non refractory patients, the c.1670+96G $>$ A and c. $1670+100 \mathrm{C}>\mathrm{T}$ changes were detected in one refractory patient and the c. $1670+131 \mathrm{G}>\mathrm{C}$ and c. $1670+$ $140 \mathrm{G}>\mathrm{C}$ changes in one non refractory patient each. Allele frequencies and statistical analyses results for all sequence changes are presented in Table 2. Allele distributions that were analyzed with regard to age ( $p$ 0.774 , Pearson $\chi 2$ analysis), gender ( $p 0.433$, Pearson $\chi 2$ Chi-Square analysis), drug response status and allele frequencies revealed no statistically significant correlation.

\section{DISCUSSION}

Approximately one-third of epilepsy patients remain untreated even though currently available drugs are used. Understanding the mechanism underlying drug response is crucial for better management strate- gies for drug resistant patients and may even lead to new drug discoveries. RLIP76 is one of these proteins that are proposed to have a role in AED transport mechanisms [4]. Our study is the first to investigate polymorphisms of the RLIP76 gene in Turkish patients. The Turkish population has a heterogeneous genetic background and high frequency of consanguinity which is around $33.9 \%$ in the Antalya region [14]. The polymorphisms we examined were mostly different from those cited by Soranzo et al. [11] and Leschziner et al. [12]. We found no correlation between the RLIP76 gene polymorphisms and drug response which agreed with both these studies. However, Awasthi et al. [4], showed that RLIP76 was expressed preferentially in the luminal surface of endothelial cell membranes of brain tissue and RLIP76 knockout mice had deficient phenytoin extrusion mechanisms in the blood-brain barrier. It was concluded that AED transport is done mainly by RLIP76 in the blood brain-barrier, therefore, it might be involved in drug resistance in epilepsy. Moreover, there is controversy regarding the location of RLIP76 in the cell and thus its function $[15,16]$. Our finding no linkage between drug response and the RLIP76 gene polymorphisms does not necessarily exclude RLIP76 having a possible role in drug response, given that the effects of nucleotide substitutions are not known.

Several other factors may be involved in the drug resistance phenomena in epileptic patients $[2,3]$. However, the reported results are conflicting. A striking example is the synonymous SNP, C3435T [17]. However, a recent meta-analysis, in which genotype association results for 3,231 drug-resistant patients and 3,524 drug-responsive or healthy controls were analyzed, failed to show any association between the

Table 1. Primer sequences designed for RLIP76 gene exons 2-10

\begin{tabular}{|c|l|l|}
\hline Exon & \multicolumn{1}{|c|}{ Forward Primer $\left(\mathbf{5}^{\prime}>\mathbf{3}\right.$ ) } & \multicolumn{1}{c|}{ Reverse Primer $\left(\mathbf{5}^{\prime}>\mathbf{3}\right.$ ') } \\
\hline 2 & GAT TTG TAA ATG CTG TGG TG & AAT ATC TAG GCA TAG GAA AA \\
\hline 3 & AGC ATA TGG ACA GTT TGA CA & AAA ACC ATG AAG TGA AG \\
\hline 4 & CTT TTC TCA GTA TCT TCT CT & CAG TTC CCC AAT CTC AGT AC \\
\hline 5 & GTA ATA GAC ACA AAT AAG TG & CAC CAC TGG ACT CCA CAA CA \\
\hline 6 & TTG CAC GTG TTG TTA GTT TA & AAA TGA CCA TTA AGA GCC TTG C \\
\hline 7 & CGT GTA GAT TGG TGG TTG GTG & AAA TGA CCA TTA AGA GCC AAG C \\
\hline 8 & GAG ACC CTA AAC AAG TGA CA & TGT AGG AAA GTC TGA GAG CT \\
\hline 9 & GTC ACA GAC AAG CAC ATC CA & ATA TGT GGT CTC TAC AAC TT \\
\hline 10 & GTC CTC TGA CTT CCT TAA GT & ACA GTA AGA TGC ACG GGT C \\
\hline
\end{tabular}


Table 2. Allele frequencies in the RLIP76 gene

\begin{tabular}{|c|c|c|c|c|c|c|}
\hline $\begin{array}{l}\text { Sequence } \\
\text { Change }\end{array}$ & Allele & $\begin{array}{c}\text { Number of } \\
\text { hromosomes } \\
\text { in Refractory } \\
\text { Patients } \\
(\%)\end{array}$ & $\begin{array}{c}\text { Number of } \\
\text { Chromosomes } \\
\text { in Non } \\
\text { Refractory } \\
\text { Patients (\%) }\end{array}$ & $\begin{array}{c}\text { Number in } \\
\text { Both } \\
\text { Groups } \\
(\%)\end{array}$ & $p$ Value & Test Applied \\
\hline c. $160-4 \mathrm{G}>\mathrm{A}$ & $\begin{array}{l}\mathrm{G} \\
\mathrm{A}\end{array}$ & $\begin{array}{l}130(44.5) \\
162(55.5)\end{array}$ & $\begin{array}{l}126(40.6) \\
184(59.4)\end{array}$ & $\begin{array}{l}256(42.5) \\
346(57.5)\end{array}$ & 0.3795 & Pearson $\chi 2$ \\
\hline c. $187 \mathrm{C}>\mathrm{G}$ & $\begin{array}{l}\mathrm{C} \\
\mathrm{G}\end{array}$ & $\begin{array}{c}2(0.7) \\
290(99.3)\end{array}$ & $\begin{array}{c}1(0.3) \\
309(99.7)\end{array}$ & $\begin{array}{c}3(0.5) \\
599(99.5)\end{array}$ & 0.6135 & Fisher's exact \\
\hline c. $1562-38 \mathrm{G}>\mathrm{A}$ & $\begin{array}{l}\mathrm{G} \\
\mathrm{A}\end{array}$ & $\begin{array}{c}260(89.0) \\
32(11.0)\end{array}$ & $\begin{array}{c}280(90.3) \\
30(9.7)\end{array}$ & $\begin{array}{c}540(89.7) \\
62(10.3)\end{array}$ & 0.7018 & Pearson $\chi^{2}$ \\
\hline c. $1670+107 \mathrm{G}>\mathrm{A}$ & $\begin{array}{l}\mathrm{G} \\
\mathrm{A}\end{array}$ & $\begin{array}{c}274(93.8) \\
18(6.2)\end{array}$ & $\begin{array}{c}296(95.5) \\
14(4.5)\end{array}$ & $\begin{array}{c}570(94.7) \\
32(5.3)\end{array}$ & 0.4720 & Pearson $\chi^{2}$ \\
\hline c. $1670+93 \mathrm{G}>\mathrm{A}$ & $\begin{array}{l}\mathrm{G} \\
\mathrm{A}\end{array}$ & $\begin{array}{c}288(98.6) \\
4(1.4)\end{array}$ & $\begin{array}{c}304(98.1) \\
6(1.9)\end{array}$ & $\begin{array}{c}592(98.4) \\
10(1.6)\end{array}$ & 0.7530 & Fisher's exact \\
\hline c. $1670+96 \mathrm{G}>\mathrm{A}$ & $\begin{array}{l}\mathrm{G} \\
\mathrm{A}\end{array}$ & $\begin{array}{c}291(99.7) \\
1(0.3)\end{array}$ & $\begin{array}{c}310(100.0) \\
0(0.0)\end{array}$ & $\begin{array}{c}601(99.8) \\
1(0.2)\end{array}$ & 0.9761 & Fisher's exact \\
\hline c. $1670+100 \mathrm{C}>\mathrm{T}$ & $\begin{array}{l}\mathrm{C} \\
\mathrm{T}\end{array}$ & $\begin{array}{c}291(99.7) \\
1(0.3)\end{array}$ & $\begin{array}{c}310(100.0) \\
0(0.0)\end{array}$ & $\begin{array}{c}601(99.8) \\
1(0.2)\end{array}$ & 0.9761 & Fisher's exact \\
\hline c. $1670+130 \mathrm{C}>\mathrm{T}$ & $\begin{array}{l}\mathrm{C} \\
\mathrm{T} \\
\end{array}$ & $\begin{array}{c}262(89.7) \\
30(10.3)\end{array}$ & $\begin{array}{c}283(91.3) \\
27(16.1)\end{array}$ & $\begin{array}{c}545(90.5) \\
57(9.5) \\
\end{array}$ & 0.6059 & Pearson $\chi^{2}$ \\
\hline c. $1670+131 G>C$ & $\begin{array}{l}\mathrm{G} \\
\mathrm{C}\end{array}$ & $\begin{array}{c}292(100.0) \\
0(0.0)\end{array}$ & $\begin{array}{c}309(99.7) \\
1(0.3)\end{array}$ & $\begin{array}{c}601(99.8) \\
1(0.2)\end{array}$ & 1.00 & Fisher's exact \\
\hline c. $1670+140 \mathrm{G}>\mathrm{C}$ & $\begin{array}{l}\mathrm{G} \\
\mathrm{C}\end{array}$ & $\begin{array}{c}292(100.0) \\
0(0.0)\end{array}$ & $\begin{array}{c}309(99.7) \\
1(0.3)\end{array}$ & $\begin{array}{c}601(99.8) \\
1(0.2)\end{array}$ & 1.00 & Fisher's exact \\
\hline
\end{tabular}

ABCB1 gene C3435T genotype and drug response in epilepsy [18]. Thus, this polymorphism seems unlikely to have an effect in predisposition to drug resistance. Zang et al. [19] have shown that human P-glycoprotein can transport phenytoin and phenobarbital in a concentration dependent fashion. However, the antiepileptic drugs carbamazepine, vaproic acid, phenytoin, lamotrigine and primidone were shown not to interact with $\mathrm{ABCB} 1, \mathrm{ABCC} 1$ and $\mathrm{ABCC} 2$ transporters in drug-resistant cancer cell lines [20]. Likewise, carbamazepine, valproate, levetiracetam, phenytoin, lamotrigine and phenobarbital have been shown not to be substrates of human MRP1, 2 and 5 in kidney cell lines [21].

These controversial data may result from factors such as the drugs used, patient demographic characteristics and epilepsy subtypes. Moreover, other genetic variants have been shown to be associated with drug response in epileptic patients. A recent study of the association between polymorphisms of the CYP2C9, CYP2C19, UGT1A1, UGT2B7, ABCB1, SCN1A genes and drug resistance found no significant association, but stratification by patient age and etiology yielded significant correlation between certain ABCB1 genotypes, patients with symptomatic epilepsy and risk of drug resistance [22].

Although there are many promising results available in the current literature, the exact factors involved in drug resistance in epilepsy have yet to be identified. Important obstacles to progress in this field may be the patient selection criteria and the definition of drug responsiveness and of refractory patients [23]. These might differ between publications and might create bias. Indeed, $20.42 \%$ of 191 drug refractory epilepsy patients were found to be pseudo refractory. That is, factors causing seizures are extraneous and re- 
evaluation of treatment would result in reduction in the number of refractory epilepsy cases [24]. In addition, optimal doses of AEDs show great variation between individuals. Therefore, it might be useful to evaluate genetic variations from two perspectives: 1) that might affect clinical efficacy of AEDs such as drug absorption, distribution and targets, and 2) that might affect tolerability and safety that are adverse reactions of AEDs, as suggested by Löscher et al. [17]. For instance, an allele of the MRP2 gene c. $1247 \mathrm{G}>$ A polymorphism was found to be strongly associated with the adverse drug reactions of carbamazepine in 146 patients with epilepsy and in 279 patients in a replication study [25]. Indeed, in a study, which included 809 patients, to evaluate adverse effects of AEDs and their relationship with a number of co-prescribed AEDs and AED loads, it was suggested that adverse effects are more prominent with individual susceptibility, AED type, and skills of the physicians than the number of co-prescribed AEDs and their load [26]. Multiple mechanisms probably underlie the phenotype. Therefore, combined effects of multiple genes and other factors, should be investigated with large families and larger sample sizes, and therefore, multi-centric collaborations are needed, especially for polymorphisms with minor allele frequencies.

\section{ACKNOWLEDGMENTS}

This study was supported by the Akdeniz University Scientific Research Projects Foundation and Coordination Unit Project number: 2006.01.0103.010 (EM).

\section{REFERENCES}

1. Sillanpää M, Schmidt D. Natural history of treated childhood-onset epilepsy: prospective, long-term population-based study. Brain. 2006; 129(Pt. 3): 617-624.

2. Steinlein OK. Gene polymorphisms and their role in epilepsy treatment and prognosis. Naunyn Schmiedebergs Arch Pharmacol. 2010; 382(2): 109-118.

3. Sisodiya SM, Marini C. Genetics of antiepileptic drug resistance. Curr Opin Neurol. 2009; 22(2): 150-156.

4. Awasthi S, Hallene KL, Fazio V, Singhal SS, Cucullo L, Awasthi YC, Dini G, Janigro D. RLIP76, a non-ABC transporter, and drug resistance in epilepsy. BMC Neurosci. 2005; 6: 61.

5. Jullien-Flores V, Dorseuil O, Romero F, Letourneur F, Saragosti S, Berger R, Tavitian A, Gacon G, Camonis
JH. Bridging Ral GTPase to Rho pathways. RLIP76, a Ral effector with CDC42/Rac GTPase-activating protein activity. J Biol Chem. 1995; 270(38): 22473-22477.

6. Awasthi S, Singhal SS, Sharma R, Zimniak P, Awasthi YC. Transport of glutathione conjugates and chemotherapeutic drugs by RLIP76 (RALBP1): a novel link between G-protein and tyrosine kinase signaling and drug resistance. Int J Cancer. 2003; 106(5): 635-646.

7. Sharma R, Singhal SS, Cheng J, Yang Y, Sharma A, Zimniak P, Awasthi S, Awasthi YC. RLIP76 is the major ATP-dependent transporter of glutathione-conjugates and doxorubicin in human erythrocytes. Arch Biochem Biophys. 2001; 391(2): 171-179.

8. Rossé C, L'Hoste S, Offner N, Picard A, Camonis J. RLIP, an effector of the Ral GTPases, is a platform for Cdk1 to phosphorylate epsin during the switch off of endocytosis in mitosis. J Biol Chem. 2003; 278(33): 30597-30604.

9. Singhal SS, Yadav S, Singhal J, Awasthi YC, Awasthi S. Mitogenic and drug-resistance mediating effects of PKCalpha require RLIP76. Biochem Biophys Res Commun. 2006; 348(2): 722-727.

10. Awasthi S, Singhal SS, Yadav S, Singhal J, Vatsyayan R, Zajac E, Luchowski R, Borvak J, Gryczynski K, Awasthi YC. A central role of RLIP76 in regulation of glycemic control. Diabetes. 2010; 59(3): 714-725.

11. Soranzo N, Kelly L, Martinian L, Burley MW, Thom M, Sali A, Kroetz DL, Goldstein DB, Sisodiya SM. Lack of support for a role for RLIP76 (RALBP1) in response to treatment or predisposition to epilepsy. Epilepsia. 2007; 48(6): 674-683.

12. Leschziner GD, Jorgensen AL, Andrew T, Williamson PR, Marson AG, Coffey AJ, Middleditch C, Balding DJ, Rogers J, Bentley DR, Chadwick D, Johnson MR, Pirmohamed M. The association between polymorphisms in RLIP76 and drug response in epilepsy. Pharmacogenomics. 2007; 8(12): 1715-1722.

13. Miller SA, Dykes DD, Polesky HF. A simple salting out procedure for extracting DNA from human nucleated cells. Nucleic Acids Res. 1988; 16(3): 1215.

14. Alper OM, Erengin H, Manguoğlu AE, Bilgen T, Cetin Z, Dedeoğlu N, Lüleci G. Consanguineous marriages in the province of Antalya, Turkey. Ann Genet. 2004; 47(2): 129-138.

15. Janigro D, Awasthi S, Awasthi YC, Sharma R, Yadav S, Singhal SS, Hallene K. RLIP76 in AED drug resistance. Epilepsia. 2007; 48(6): 1218-1219.

16. Sisodiya S, Thom M. Response to Janigro et al. Epilepsia. 2007; 48(6): 219-220.

17. Löscher W, Klotz U, Zimprich F, Schmidt D. The clinical impact of pharmacogenetics on the treatment of epilepsy. Epilepsia. 2009; 50(1): 1-23. 
18. Haerian BS, Roslan H, Raymond AA, Tan CT, Lim KS, Zulkifli SZ, Mohamed EH, Tan HJ, Mohamed Z. ABCB1 C3435T polymorphism and the risk of resistance to antiepileptic drugs in epilepsy: a systematic review and meta-analysis. Seizure. 2010; 19(6): 339-346.

19. Zhang C, Kwan P, Zuo Z, Baum L. In vitro concentration dependent transport of phenytoin and phenobarbital, but not ethosuximide, by human P-glycoprotein. Life Sci. 2010; 86(23-24): 899-905.

20. Rivers F, O’Brien TJ, Callaghan R. Exploring the possible interaction between antiepilepsy drugs and multidrug efflux pumps; in vitro observations. Eur J Pharmacol. 2008; 598(1-3): 1-8.

21. Luna-Tortós C, Fedrowitz M, Löscher W. Evaluation of transport of common antiepileptic drugs by human multidrug resistance-associated proteins (MRP1, 2 and 5) that are overexpressed in pharmacoresistant epilepsy. Neuropharmacology. 2010; 58(7): 1019-1032.

22. Sánchez MB, Herranz JL, Leno C, Arteaga R, Oterino A, Valdizán EM, Nicolás JM, Adín J, Armijo JA. Genetic factors associated with drug-resistance of epilep- sy: relevance of stratification by patient age and aetiology of epilepsy. Seizure. 2010; 19(2): 93-101.

23. Berg AT. Identification of pharmacoresistant epilepsy. Neurol Clin. 2009; 27(4): 1003-1013.

24. Viteva EI, Zahariev ZI. Pseudoresistance in patients with epilepsy characteristics and determining factors. Folia Med (Plovdiv). 2009; 51(2): 33-39.

25. Kim WJ, Lee JH, Yi J, Cho YJ, Heo K, Lee SH, Kim SW, Kim MK, Kim KH, Lee BI, Lee MG. A nonsynonymous variation in MRP2/ABCC2 is associated with neurological adverse drug reactions of carbamazepine in patients with epilepsy. Pharmacogenet Genom. 2010; 20(4): 249-256.

26. Canevini MP, De Sarro G, Galimberti CA, Gatti G, Licchetta L, Malerba A, Muscas G, La Neve A, Striano P, Perucca E, and the SOPHIE Study Group. Relationship between adverse effects of antiepileptic drugs, number of coprescribed drugs, and drug load in a large cohort of consecutive patients with drug-refractory epilepsy. Epilepsia. 2010; 51(5): 797-804. 